\title{
Factors Affecting Blood Pressure Control among Hypertensive Patients Attending Primary Healthcare Facilities in Western Jamaica
}

\author{
VH Waugh-Brown
}

\begin{abstract}
Objective: To identify patient-related factors that act as barriers to hypertension control. Methods: A cross-sectional study of 365 patients who were diagnosed with primary hypertension and attended primary healthcare facilities in western Jamaica was carried out. A pretested questionnaire was administered, and the patients' blood pressure and body mass index were taken and calculated. Inferential statistics were used to interpret the data. Chi-square and Fischer's exact tests were used to analyse the differences in dichotomous variables. A p-value of $\leq 0.05$ was regarded as statistically significant. Two focus group discussions and $10 \mathrm{in}$-depth interviews provided qualitative data.

Results: Of the 365 participants, only $30.1 \%$ had blood pressure readings within normal limits. The blood pressure was statistically significantly higher in those who last smoked under one year $(\mathrm{p}=0.018)$, those who consumed alcohol $(\mathrm{p}=0.021)$, those who reported high stress levels $(\mathrm{p}=0.020)$ and those with a weak support system $(\mathrm{p}=0.012$; Spearman's rank correlation coefficient $=0.131$ ). Knowledge deficit was also statistically significant where $55.1 \%$ believed that hypertension could be cured or were unsure and $27.5 \%$ denied personal responsibility in achieving control. Patients who had been diagnosed 11 years or more were more likely to be uncontrolled $(\mathrm{p}=0.010)$. Medication adherence $(\mathrm{p}=0.056)$, alternative medicine $(\mathrm{p}=$ $0.476)$, diet $(\mathrm{p}=0.108)$, exercise $(\mathrm{p}=0.568)$ and obesity $(\mathrm{p}=0.941)$ showed no statistically significant relationship.

Conclusion: Smoking, alcohol consumption, stress, level of awareness and support system were significant modifiable determinants of blood pressure control. Clinicians often place much emphasis on medication adherence, diet and exercise. However, these modifiable contributing factors are often overlooked in the management of hypertension. Addressing these issues could result in a significant improvement in blood pressure control.
\end{abstract}

Keywords: Blood pressure, hypertension, lifestyle, primary healthcare facilities

\section{Factores que afectan el control de la presión arterial entre los pacientes hipertensos que asisten a centros de atención primaria en Jamaica occidental}

\author{
VH Waugh-Brown
}

\begin{abstract}
RESUMEN
Objetivo: Identificar factores relacionados con el paciente que actúan como barreras al control de la hipertensión.
\end{abstract}

From: School of Nursing, The University of the West Indies, Mona, Kingston, Jamaica, West Indies.
Correspondence: Mrs VH Waugh-Brown, School of Nursing, The University of the West Indies, Mona, Kingston 7, Jamaica, West Indies. Email: veronica.waughbrown02@uwimona.edu.jm 
Métodos: Se realizó un estudio transversal de 365 pacientes que fueron diagnosticados con hipertensión primaria y atendidos en centros de salud de atención primaria en el occidente de Jamaica. Se administró un cuestionario previamente probado, y se tomaron y calcularon los indices de presión arterial e indice de masa corporal de los pacientes. Se utilizaron estadísticas inferenciales para interpretar los datos. Se utilizaron las pruebas exactas de Chi-cuadrado $y$ Fischer para analizar las diferencias en las variables dicotómicas. Un valor $\mathrm{p}$ de $\leq 0.05$ se consideró estadísticamente significativo. Dos discusiones de grupos focales y 10 entrevistas en profundidad proporcionaron datos cualitativos.

Resultados: De los 365 participantes, sólo el 30.1\% tuvo lecturas de presión arterial dentro de los límites normales. La presión arterial fue estadísticamente significativamente mayor en aquellos que fumaron por última vez menos de un año $(\mathrm{p}=0.018)$, los que consumían alcohol $(\mathrm{p}=0.021)$, los que reportaron altos niveles de estrés $(\mathrm{p}=0.020)$, y aquellos con un sistema de apoyo débil $(\mathrm{p}=0.012$; coeficiente de correlación de rango de Spearman $=0.131)$. El déficit de conocimiento también fue estadísticamente significativo en el 55.1\% que creía que la hipertensión podía ser curada o no estaba seguro, y en el 27.5\% que negaba la responsabilidad personal de lograr el control. Los pacientes que habian sido diagnosticados 11 años o más, eran más propensos a ser descontrolados $(\mathrm{p}=0.010)$. El cumplimiento de la medicación $(\mathrm{p}=0.056)$, la medicina alternativa $(\mathrm{p}=0.476)$, la dieta $(\mathrm{p}=0.108)$, los ejercicios $(\mathrm{p}=0.568)$ y la obesidad $(\mathrm{p}=0.941)$ no mostraron ninguna relación estadísticamente significativa.

Conclusión: El tabaquismo, el consumo de alcohol, el estrés, el nivel de conciencia, y el sistema de apoyo, fueron factores determinantes modificables significativos del control de la presión alterial. Los clínicos a menudo ponen mucho énfasis en el cumplimiento de la medicación, la dieta y el ejercicio. Sin embargo, los mencionados factores contribuyentes modificables a menudo se pasan por alto en el tratamiento de la hipertensión. Abordar estos problemas podría traer consigo una mejoría significativa en el control de la presión arterial.

Palabras clave: Presión arterial, hipertensión, estilo de vida, centros de atención primaria

\section{West Indian Med J 2018; 67 (2): 132}

\section{INTRODUCTION}

Hypertension, a silent-killer, is a major public health challenge worldwide $(1,2)$ that is being fuelled by the demographic and epidemiologic transitions sweeping across the world $(3,4)$. The World Health Organization indicated that in 2008 , as many as $40 \%$ of adults aged 25 years or older had been diagnosed with hypertension and the burden of the disease was greater in lowerand middle-income countries (1). One in every three Jamaicans aged 30 years or older was affected by hypertension (5), with a ratio of approximately 2.3 females to 1 male (6).

Hagley pointed out that although $90 \%$ of cases were related to genetic disposition, hypertension was not inherited (7). Rather, it developed as a result of interaction between the inherited predisposition and a number of lifestyle-related factors (7). These behavioural factors include cigarette-smoking, obesity, excess salt intake, excess alcohol intake, physical inactivity, and stress (1,
$6,8)$. Therefore, lifestyle modifications play an integral role in the prevention and control of hypertension (1, $8)$. Over the years, more effective treatment has been made available for managing hypertension. However, a study of a multinational population conducted in 200309 indicated a rate of control for patients on treatment at $32.5 \%$. Rates of control were better in developed countries; developing countries were still grappling to improve control (9).

In Jamaica, the National Health Fund (NHF) and the abolition of user fees in the public health system were introduced in 2003 and 2008 respectively to help offset the economic burden of the condition on the individual $(5,10,11)$. However, despite all the major in-roads to enhance control, the rates remained low $(12,13)$. Uncontrolled hypertension predisposed to conditions with high morbidity and mortality rates such as coronary artery disease, cerebrovascular accidents and renal impairment $(1,6,14)$. It was therefore necessary to 
determine patient-related barriers to blood pressure control and use this to inform programmes that could assist in achieving optimal blood pressure control. Hence, the high prevalence of hypertension and the low rate of control were the driving forces behind this research which investigated patient-related factors that influenced blood pressure control among persons living with hypertension.

\section{SUBJECTS AND METHODS}

A descriptive, cross-sectional study of patients who were diagnosed with primary hypertension and attended medical clinics at primary healthcare facilities in western Jamaica was conducted over a two-month period. Quantitative (a questionnaire survey) and qualitative (focus group discussions and in-depth interviews) methods were utilized to collect data. Participants in the quantitative survey were not included in the qualitative component. Of the 9106 patients who were registered on the Region's Chronic Non-Communicable Disease Hypertension Register, a sample size of 365 was calculated using Sample Size Calculator by Raosoft Inc (www.raosoft.com/samplesize.html). Twenty-two of the 54 health centres in the four parishes comprising the Region were sampled through stratified randomization. The proportion of participants required from each parish was manually calculated.

Inclusion criteria were: patients with primary hypertension who had been diagnosed for one complete year or more, who were enlisted on the Hypertension Register of the Region, who were aged 18 years or above and attended medical clinics within the parishes on the days of visit. Exclusion criteria were: patients diagnosed with secondary hypertension, patients diagnosed with primary hypertension for less than a year, those below 18 years of age or having co-morbid conditions that required followup care at secondary facilities (eg renal failure). All the hypertensive patients who met the criteria were invited to participate in the study, nine of whom declined participation. A total of 365 persons participated in the study.

Ethical approval was obtained prior to commencing the study from the The University of the West Indies Ethics Committee and the Regional Technical Director of the Western Regional Health Authority, Jamaica. Written informed consent was obtained from all who were eligible and willing to participate in the study.

A pre-tested questionnaire yielded demographic data as well as data regarding knowledge, attitude and practice towards hypertension. The blood pressure of the participants was measured using a reliable mercury sphygmomanometer and their body mass index (BMI) calculated. Blood pressure readings of $\geq 140 / 90 \mathrm{mmHg}$ were considered uncontrolled, and a BMI of $\geq 30 \mathrm{~kg} / \mathrm{m}$ was considered obese. Nine trained research assistants helped with the administration of the questionnaires.

The data were analysed with the aid of Statistics Package for Social Sciences (SPSS) 17.0 software. Inferential statistics were used to interpret the data. Differences in dichotomous variables were analysed using Chi-square or Fischer's exact test, as appropriate. A $p$-value of 0.05 was considered to be of statistical significance. The results were presented with the aid of narratives, tables and graphs.

The qualitative component consisted of 10 in-depth interviews with 10 patients whose blood pressure was poorly controlled and two focus group discussions with patients whose blood pressure was controlled for their past three regular clinic visits. Interview schedule and moderator guide facilitated the process. Perceptions regarding factors contributing to blood pressure control were explored and the themes identified and analysed. The responses were developed into scripts and manually analysed. Themes were extracted and the information further analysed and interpreted using the Framework Approach (15). The interpretations were used to complement findings from the quantitative arm of the study.

\section{RESULTS}

A total of 365 patients participated in the quantitative arm of the study, $54.8 \%$ of whom were in the age group of $\geq 60$ years. Only 110 participants $(30.1 \%)$ had blood pressure readings within normal limits. As age increased, the prevalence of hypertension increased. Figure 1 shows that the rate of blood pressure control declined after 10 years of being diagnosed.

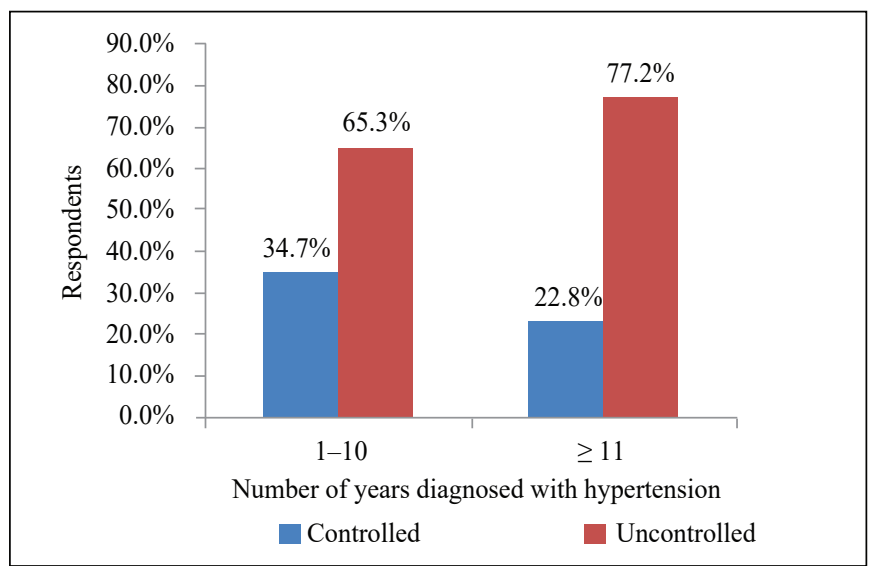

Fig. 1: Blood pressure control in relation to length of period of diagnosis $(p=0.010)$ 


\section{Stress and blood pressure control}

Blood pressure was more likely to be controlled among respondents who reported to be rarely or never stressed $(p=0.020$; Spearman's rank correlation coefficient $=-0.115)$. Females $(35.8 \%)$ were more likely to feel stressed than males (20\%; Fischer's exact $=0.009)$. Married persons showed the highest incidence of being often/always stressed $(39 \%)$ when compared to those with other union status. Table 1 outlines the relationship between patients' stress and blood pressure control.

Table 1: Relationship between stress and blood pressure control

\begin{tabular}{llll}
\hline Blood pressure & $\begin{array}{l}\text { Often/ } \\
\text { always } \\
\text { stressed }\end{array}$ & $\begin{array}{l}\text { Rarely/ } \\
\text { never } \\
\text { stressed }\end{array}$ & Total \\
\hline Controlled & $27(22.7 \%)$ & $82(33.9 \%)$ & $109(30.2 \%)$ \\
Uncontrolled & $92(77.3 \%)$ & $160(66.1 \%)$ & $252(69.8 \%)$ \\
Total & $119(33.0 \%)$ & $242(67.0 \%)$ & $361(100.0 \%)$ \\
\hline
\end{tabular}

\section{Support and blood pressure control}

Of the sample, 207 respondents (56.7\%) were either unemployed or retired. Among this group, children were the main source of support $(60.4 \% ; n=125)$, followed by spouses. Respondents who received support from their spouses had the highest level of blood pressure control $(39.5 \% ; n=17)$. The blood pressure of those supported by the government and by friends was not controlled $(0 \%)$. A Spearman's rank correlation coefficient of 0.160 indicated a weak positive correlation significant at 0.05 (Table 2).

Table 2: Relationship between primary support system of unemployed respondents and blood pressure control

\begin{tabular}{lll}
\hline Support & Frequency & $\begin{array}{l}\text { Blood pressure } \\
\text { controlled (\%) }\end{array}$ \\
\hline Spouse & $43(20.8 \%)$ & 39.5 \\
Children & $125(60.4 \%)$ & 28.8 \\
Other relatives & $11(5.3 \%)$ & 9.1 \\
Friends & $3(1.4 \%)$ & 0.0 \\
Government & $6(2.9 \%)$ & 0.0 \\
Other & $19(9.2 \%)$ & 26.3 \\
Total & $207(100.0 \%)$ & 100.0
\end{tabular}$p=0.143 ; \mathrm{r}=0.160$

All persons diagnosed with hypertension were eligible for anti-hypertensive drug benefits through the NHF, a government-administered social support programme. However, only 131 persons $(39.9 \%)$ were registered to access the benefits. Of this number, 38.2\% had blood pressure readings within the controlled limit, whereas only $25.6 \%$ of the 234 respondents who were not on the programme had controlled blood pressure readings $(p=$ 0.012; Spearman's rank correlation coefficient $=0.131$ ).

\section{Knowledge and blood pressure control}

A total of 201 respondents $(55.1 \%)$ were either unsure or believed that hypertension could be cured. This was more evident as age increased ( $p=0.003$ ) or literacy level decreased $(p=0.042)$. As many as $27.5 \%(\mathrm{n}=98)$ of the respondents considered that the major responsibility for their blood pressure control was on others (government, doctors, nurses, relatives) $(p=0.001)$. Males were more likely to hold this view than females.

\section{Cigarette-smoking and blood pressure control}

Eighty-six respondents $(23.6 \%)$ had smoked cigarettes at some point in their lives. Persons who last smoked within one year of the interview had a higher rate of uncontrolled blood pressure compared to those who last smoked over a year $(p=0.018)$ prior to the interview (Table 3).

Table 3: Blood pressure control according to smoking status

\begin{tabular}{llll}
\hline $\begin{array}{l}\text { History of } \\
\text { smoking }\end{array}$ & $\begin{array}{l}\text { Number of } \\
\text { respondents }\end{array}$ & Controlled & Uncontrolled \\
\cline { 1 - 3 } Never smoked & 279 & $87(31.2 \%)$ & $192(68.8 \%)$ \\
Smoked & 86 & $23(26.7 \%)$ & $63(73.3 \%)$ \\
$\begin{array}{l}\text { Last smoked } \\
\geq 1 \text { year }\end{array}$ & 67 & $20(29.9 \%)$ & $47(70.1 \%)$ \\
$\begin{array}{l}\text { Last smoked } \\
<1 \text { year }\end{array}$ & 14 & $0(0.0 \%)$ & $14(100.0 \%) \quad p=0.018$ \\
\hline
\end{tabular}

\section{Alcohol and blood pressure control}

Thirty-five subjects (9.6\%) consumed alcohol. Among this group, $5(14.3 \%)$ had blood pressure readings within the normal range whereas from among the $330(90.4 \%)$ who did not consume alcohol, $105(31.8 \%)$ had controlled blood pressure readings (Fischer's exact $=0.021$ ).

\section{Practice and blood pressure control}

No statistically significant relationship to blood pressure control was found in the following areas: exercise (household chores were included as exercise): $p=0.568$; diet: $p=0.108$; medication adherence: $p=0.056$; alternative medicine: $p=0.476$; keeping of appointments: $p=0.388$; and BMI: $p=0.471$.

\section{DISCUSSION}

Significant advancements had been made in the management of hypertension. However, despite these strides, this study found that blood pressure control remained low. Only $30.1 \%$ of the respondents demonstrated adequate blood pressure control. This finding was similar to that from a 2003 study by Duff and Wilks (12). 
Consistent with other reports $(1,6,8)$, stress, alcohol, cigarette-smoking, weak support system and knowledge deficit were modifiable factors that emerged as significant barriers to blood pressure control. These factors are often overlooked in the direct management of patients. Age and length of period since diagnosis were non-modifiable factors identified. Older adults are more likely to be affected with hypertension. Given the demographic shift (4), there is an urgent need for strategic plans to mitigate the ominous predictable consequences.

The importance of medication adherence, diet and exercise compliance in the management of patients with hypertension is well documented and emphasised. However, equal emphasis on other lifestyle practices is needed. Stress was one of the factors identified as a barrier to blood pressure control and has been scientifically argued to contribute to the elevation of blood pressure (16). The focus groups perceived stress as a major determinant of uncontrolled hypertension while the rate of blood pressure control for persons who reported to be rarely or never stressed was statistically significantly better compared to those who reported to be stressed most times $(p=0.020)$. This finding lends support for stress management to be integrated into the plan of care for patients. It would be insightful for primary healthcare providers to incorporate aspects of mental health (eg stress evaluation, counselling and coping skill techniques) as a crucial area in the routine management of hypertension.

Normative figures played a key role in helping patients with hypertension to attain and maintain blood pressure control (17). Patients with strong family support were more likely to have blood pressure readings within normal limits. Participants of the study's focus group discussions and in-depth interviews believed that the caring input of normative figures contributed to compliance with treatment and ultimately better control. Beneficiaries of the national social support programme, the NHF, achieved greater success rates $(p=0.012)$. However, the reach was limited (39.9\%) and is worth an investigation by the NHF. Strengthening support systems at the family and national levels can positively impact blood pressure control.

Similar to other reports $(1,6)$, cigarette-smoking $(p=0.018)$ and alcohol consumption $(p=0.021)$ had a negative impact on blood pressure control. Both cigarettes and alcohol are readily available habit-forming drugs that may appeal to hypertensive patients especially when they are under stress. These findings can be useful to primary healthcare providers as they educate the hypertensive patients at follow-up visits.
Health literacy is integral to the management of hypertension as a person's health beliefs influence health outcomes. Significant knowledge gaps were identified especially as in relation to the patient assuming responsibility for control of blood pressure $(p=0.000)$ and whether or not hypertension could be cured. It was clear that the old health messages had failed. Re-structuring health messages through a collaborative approach that involves the entire health team (including the patient and normative figures) and consistent reinforcement may be necessary to dispel misconceptions and help to bring about behavioural change.

Patients who received care from private healthcare facilities were not included in this study. Hence, comparisons and inferences are applicable only to the primary healthcare setting. Also, the study focussed primarily on patient-related factors and did not include health systemrelated factors which are also important elements for control. Some participants (11.5\%) reported chores as their exercise, and the BMI was missing for $12.1 \%$ of the respondents as they were wheelchair-bound. These could have affected the results of the relationship among exercise, BMI and blood pressure control.

\section{CONCLUSION}

Healthy lifestyle practices play a crucial role in the control of hypertension. Stress, support system, cigarette-smoking, alcohol consumption and knowledge gaps were factors that this study had identified as being significant or associated with blood pressure control. These factors need to be addressed in the plan of care for patients with hypertension. A re-orientation of health education and promotion strategies and a holistic team management approach are necessary to effect better and sustainable control. The findings of this study can be used to inform and strengthen the management of hypertension in primary healthcare.

\section{ACKNOWLEDGEMENTS}

Special thanks go to Dr K James (Lecturer), Dr J Goulbourne (Research Supervisor) and Dr D HolderNevins (Lecturer), Department of Community Health and Psychiatry, The University of the West Indies, Mona, Jamaica, West Indies, who provided guidance in conducting the study.

\section{REFERENCES}

1. World Health Organization. A global brief on hypertension: silent killer, global public health crisis [Internet]. World Health Organization; 2013 [cited 2015 May 4]. Available from: http://apps.who.int/iris/bitstream/10665/79059/1/WHO_DCO_WHD_2013.2_eng.pdf. 
2. Kearney PM, Whelton M, Reynolds K, Muntner PK, He J. Global burden of hypertension: analysis of worldwide data. The Lancet 2005; 365: 217-23.

3. Wahdan M. The epidemiological transition. Eastern Mediterranean Health Journal 1996; 2: 8-20.

4. Eldemire-Shearer D. Ageing: the response yesterday, today and tomorrow. West Indian Med J 2008; 57: 577-88.

5. Ministry of Health, Jamaica. Guideline for the management of hypertension. 2007.

6. The World Bank. Non-communicable diseases in Jamaica: moving from prescription to prevention (conference edition) [Internet]. The World Bank; 2010 [cited 2015 Aug 31]. Available from: http://siteresources. worldbank.org/INTLAC/Resources/NCDsJamaica.pdf.

7. Hagley K. You don't have to get high blood pressure. Jamaica Gleaner. 2007 May 16.

8. Lemogoum D. Challenge for hypertension prevention and control worldwide: the time for action. J Clin Hypertens 2014; 16: 554-6.

9. Chow CK, Teo KK, Rangarajan S, Islam S, Gupta R, Avezum A et al. Prevalence, awareness, treatment and control of hypertension in rural and urban communities in high, middle and low income countries. JAMA 2013; 310: 959.

10. Chao S. Economic impact of non-communicable disease in the Caribbean [Internet]. The World Bank, Caribbean Health Financing
Conference, Jamaica; 2013 [cited 2015 May 14]. Available from: http:// www.nhf.org.jm/cchfi/images/pdf/8th_CCHFI_presentations/Day 2/ WB_Presentation_at_CHFC_Jamaica_2013.pdf.

11. Campbell A. The abolition of user fees in the Jamaican public health system: impact on access, care provided and the work of the professional nurse [Internet]. Victoria University of Wellington; 2013 [cited 2015 May 20]. Available from: http://researcharchive.vuw.ac.nz/xmlui/ handle/10063/2718.

12. Duff E, Wilks R. Six-month hypertension intervention study: one year follow-up. West Indian Med J 2003; 52: 219-22.

13. Asani M, Brown P, O’Connor D, Lewis T, Win S, Reid M. A clinical audit of the quality of care of hypertension in general practice. West Indian Med J 2005; 54: 176-80.

14. World Life Expectancy. Health profile: Jamaica [Internet]. World Life Expectancy [cited 2015 May 23]. Available from: http://www.worldlifeexpectancy.com/country-health-profile/jamaica.

15. Pope C, Mays N. Qualitative research in health care. $2^{\text {nd }}$ edition. London: BMJ Books; 2004.

16. Mustacchi P. Stress and hypertension. West J Med 1990; 153: 180-5.

17. Osamor P. Social support and management of hypertension in southwest Nigeria. Cardiovasc J Afr 2015; 26: 29-33. 